J. Perinat. Med.

11 (1983) 85

\section{Fetal heart rate monitoring on the operating table immediately before delivery by cesarean section}

\author{
M. Pluta, J. W. Dudenhausen, J. Gesche, E. Saling \\ Unit of Perinatal Medicine, The Free University of Berlin, \\ Department of Obstetrics, Berlin-Neukölln
}

\section{Introduction}

During the past 10 years there has been an increase in the rate of cesarean sections, and at the same time interest has increased regarding the effects of anesthesia on mother, fetus and newborn. In spite of improved procedures in anesthetics, in some cases newborns are in a depressed state after delivery by cesarean section. According to CRAWFORD [2] this is caused by drugs or biochemical factors or a mixture of both. While the barbiturates are the primary depressants of the infant from general anesthesia, this cause of depression is reduced to a minimum during regional anesthesia such as an epidural. The chief factors causing biochemical depression are maternal hyperventilation [13], position of the mother during the operation and the duration of the induction-delivery-interval. Many authors [ 1 , $2,8,11,16]$ have pointed out how important the mother's position is during the operation, and how this influences the state of the newborn. In this way the frequency of fetal hazards caused by the supine hypotension vena cava-compression syndrome can be reduced by placing the mother in a lateral position of $15^{\circ}$ deviation to the left.

The question as to the optimal duration of the induction-delivery-interval in non-emergency cesareans has been a topic of interest over the past ten years. Some authors $[6,14]$ are in favor of a long induction-delivery-interval since the risk of depression of the newborn due to drugs
Curriculum vitae

MATTHIAS PLUTA was born in 1950 in ClausthalZellerfeld, Germany. He studied medicine at the Free University of Berlin, and graduated from there in 1978. Since 1979 he has been working at the Unit of Perinatal Medicine of the Free University of Berlin.

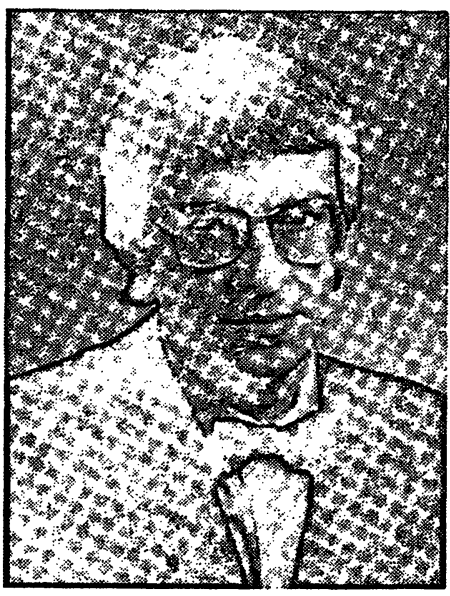

can be lessened through the exponential fall in barbiturate concentration in maternal and fetal plasma [3].

In some cases even when the mother is lying in a lateral position, a supine-hypotension-syndrome occurs leading to an increase in fetal impairment $[2,8,11,15]$ during a prolonged inductiondelivery-interval.

In 1970 SALING [12] suggested that another possible reason for the worsening in the fetal condition could be the loss of the oxygen conserving adaptation of the fetal circulation induced by barbiturates. In this way vasoconstriction which occurs in the fetus in compensated chronic respiratory insufficiency as a protection for the heart and brain (organs most sensitive to hypoxia) is partially removed, and a generalized increase of 
hypoxia and acidosis follows. In order to study such an impairment to the fetus during the interval just prior to surgery we have continued to record the fetal heart rate on the operating table during cesarean sections for several years as a routine practice. The results from a period of 5 years are given in the following study.

\subsection{Patients and anesthetic procedures}

Monitoring of the fetal heart rate on the operating table was conducted during the period from January 1, 1976 to December 31, 1980 in 277 cesarean sections under general anesthesia. Elective cesarean sections, cesarean sections with epidural anesthesia, twin births and breech presentation were not included in the evaluation. Of the 277 cases evaluated, 178 cesarean sections were performed for arrest of labor in the pelvic inlet and 99 for prolonged fetal preacidosis or acidosis.

After being transported to the operating room all patients were placed in a left lateral position $\left(15^{\circ}\right)$ on the operating table. The fetal heart rate was registered with a cardiotocograph (HP $8020 \mathrm{~A}$ ) from a scalp electrode until the uterine incision was made.

Immediately prior to anesthesia, $0.25 \mathrm{mg}$ of Atropine was given intravenously as a premedica- tion. The injection of $200-300 \mathrm{mg}$ of Thiopental (Trapanal ${ }^{\circledR}$ ) followed, the preoxygenation to compensate for the relaxation apnea. Endotracheal intubation was done after muscle relaxation with $1 \mathrm{mg} / \mathrm{kg} \mathrm{BW}$ succinylcholine. Up to the delivery of the fetus anesthesia was maintained under controlled ventilation using a mixture of nitrous oxide and oxygen with a ratio of $2: 1$. Immediately before delivery a nitrous oxide washout was performed. After the infant had been delivered, the mother was placed in a horizontal position and under continuous relaxation infusion, the analgesia was maintained with $0.3 \mathrm{mg}$ Fentanyl.

When it was clinically necessary (apnea or dyspnea) the newborn underwent endotracheal aspiration, intubation and ventilation. In depressed infants with an actual $\mathrm{pH}$ below 7.10 from the umbilical artery blood, a buffer solution of sodium bicarbonate $\left(8.4 \% \quad \mathrm{NaHCO}_{3}, 4 \mathrm{ml} / \mathrm{kg} \mathrm{BW}\right)$ was given into the clamped umbilical vein.

\section{Results}

We subdivided the total group of 277 cesarean sections with a cardiogram on the operating table into "infants at hypoxic risk" and "infants without hypoxic risk". Ninety-nine infants were found

Tab. I. Review of 277 cesarean sections $\tilde{\mathrm{x}}=\operatorname{median}($ minimum and maximum)

\begin{tabular}{|l|c|c|}
\hline $\begin{array}{l}\text { Indication for } \\
\text { cesarean section }\end{array}$ & Arrest of labor & $\begin{array}{l}\text { Preacidosis or } \\
\text { acidosis }\end{array}$ \\
\hline No. of subjects & 178 & 99 \\
\hline $\begin{array}{l}\text { Primi para } \\
\text { Multi para }\end{array}$ & 132 & 67 \\
& 46 & 32 \\
\hline Patients age (years) & $\tilde{x}=27.7(18-43)$ & $\tilde{x}=27.3(16-45)$ \\
\hline Birth weight (g) & $\tilde{x}=3450(1570-4940)$ & $\tilde{x}=3240(1100-4790)$ \\
\hline $\begin{array}{l}\text { Anesthesia-induction- } \\
\text { delivery-time (min) }\end{array}$ & $\tilde{x}=10.1(4-23)$ & $\tilde{x}=7.9(3-18)$ \\
\hline $\begin{array}{l}\text { Incision- } \\
\text { delivery-time (min) }\end{array}$ & $\tilde{x}=7.9(3-22)$ & $\tilde{x}=5.9(3-15)$ \\
\hline $\begin{array}{l}\text { Duration of } \\
\text { cardiogram (min) }\end{array}$ & $\tilde{x}=13.1(4-30)$ & $\tilde{x}=8.1(4-20)$ \\
\hline
\end{tabular}


to be at risk when fetal blood analysis during labor demonstrated prolonged preacidosis or an acidosis. In 178 cesarean sections performed for arrest of labor in the pelvic inlet, the infants were primarily regarded as nonrisk cases.

\subsection{Cesarean sections for arrest of labor in the pelvic inlet}

Details of parity, patient's age and birth weight of the infants are given in Tab. I. The median for the induction-delivery-interval (IDI) was 10.1 minutes and the interval between incision and delivery was 7.9 minutes. The duration of the fetal heart rate recording on the operating table ranged from 4 to 30 minutes $(\tilde{\mathrm{x}}=13.1 \mathrm{~min})$.

\subsection{Condition of the newborn}

The biochemical and clinical condition of the newborn is given in Tab. II. Of the 178 newborns, 161 were clinically vigorous (APGAR score $\geqslant 7$ points) and $17(9.6 \%)$ were depressed ( $\leqslant 6$ points).

The actual $\mathrm{pH}$ in the umbilical artery blood measured $\geqslant 7.20$ in 159 cases, and was acidotic in 19 cases $(10.7 \%)$. Six infants $(3.4 \%)$ were acidotic and also clinically depressed (APGAR score $\leqslant 6$, actual $\mathrm{pH}<7.20)$. One infant $(0.6 \%)$ had a clinically moderate state of depression combined with an advanced acidosis (APGAR score $\leqslant 4$, actual $\mathrm{pH}<7.10)$; 54 newborns $(30 \%)$ had to be artificially ventilated for a short time, and 6 infants received buffer solution injected into the umbilical vein.
The condition of the newborn as a function of the anesthesia-induction-delivery-interval is given in Figs. 1 and 2. There was no significant correlation between the APGAR score and the anesthesiainduction-delivery-interval. There was a correlation coefficient for the APGAR score of $r=-0.072$ with $p>0.05$. Similarly there was no significant correlation for the $\mathrm{pH}$ values of the umbilical cord artery to the anesthesia-induction-delivery interval $(r=0.016 ; p>0.05)$.

\subsection{Cardiotocograms}

The cardiotocograms from the last 30 minutes before the patient was placed on the operating table were normal in 107 cases, suspicious in 39 , prepathological in 27 and pathological in 5 (according to HAMMACHER [4]). Seventy-two fetal blood analyses were performed because of suspicious or pathological patterns in the cardiotocogram which showed a normal acid-base state.

The evaluation of the cardiotocograms was differentiated according to single parameters on the HAMMACHER score. The oscillation types (short term variability) according to HAMMACHER for the last 30 minutes of the cardiotocogram before the patient was moved onto the operating table are given in Tab. IIIa. In comparison to this, one can see a clear shift in the direction of lower oscillation frequencies and amplitude in the oscillation pattern on the cardiogram on the operating table (Tab. IIIb).

In 80 cardiograms (44.9\%) there was no change of oscillation pattern compared to the previous

Tab. II. Clinical and acid-base state of the newborn after cesarean section

\begin{tabular}{|c|c|c|c|c|c|c|c|c|c|c|c|c|}
\hline $\begin{array}{l}\text { Indication } \\
\text { for } \\
\text { cesarean } \\
\text { section }\end{array}$ & $0-2$ & | 3-4 & 5-6 & | $7-8$ & $9-10$ & $<7.00$ & $\begin{array}{l}7.00- \\
7.09\end{array}$ & $\begin{array}{l}7.10 \\
7.19 \\
\end{array}$ & $\begin{array}{l}7.20- \\
7.29\end{array}$ & $\geqslant 7.30$ & $\mid \begin{array}{l}\text { Apgar } \\
\leqslant 4 \\
\text { and } \\
\text { pH act } \\
<7.10\end{array}$ & $\begin{array}{l}\text { Apgar } \\
\leqslant 6 \\
\text { and } \\
\mathrm{pH} \text { act } \\
<7.20 \\
\end{array}$ \\
\hline $\begin{array}{l}\text { Arrest of } \\
\text { labor } \\
(n=178)\end{array}$ & 1 & $\frac{12}{17=}$ & 14 & 51 & 110 & $\frac{1}{1}$ & $\overbrace{9=10.7}^{7}$ & 11 & 92 & 67 & $1=0.6 \%$ & $6=3.4 \%$ \\
\hline $\begin{array}{l}\text { Preacidosis } \\
\text { or } \\
\text { acidosis } \\
(n=99)\end{array}$ & 2 & $\frac{18}{30=30.3}$ & $\frac{.20}{\%}$ & 27 & 42 & 6 & $\overbrace{5=65.7}^{18}$ & 41 & 33 & 1 & $5=5.1 \%$ & $24=24.2 \%$ \\
\hline
\end{tabular}




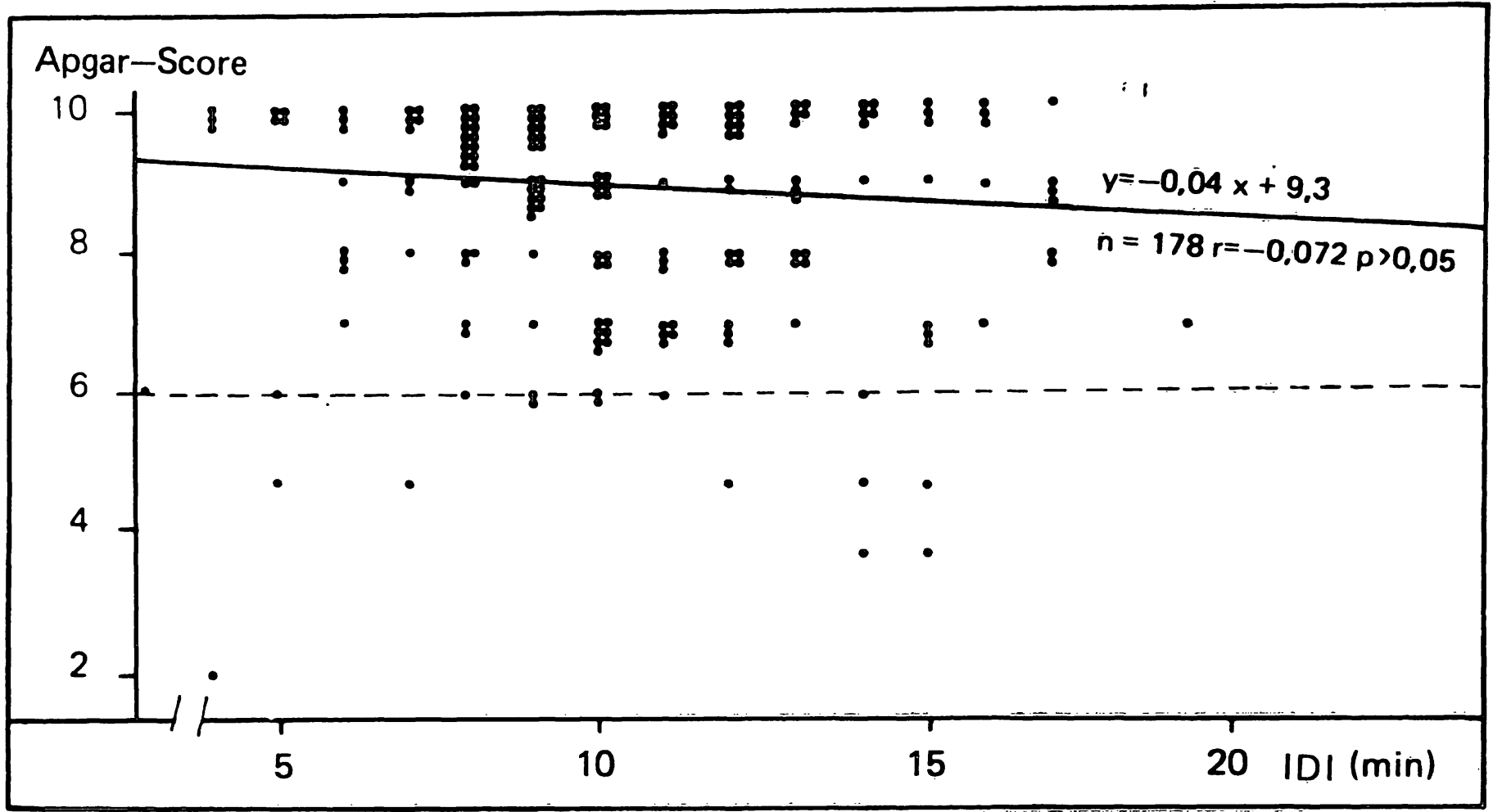

Fig. 1. Correlation between APGAR score 1 minute post partum and the induction-delivery-interval (IDI) in cases with cesarean section for arrest of labor

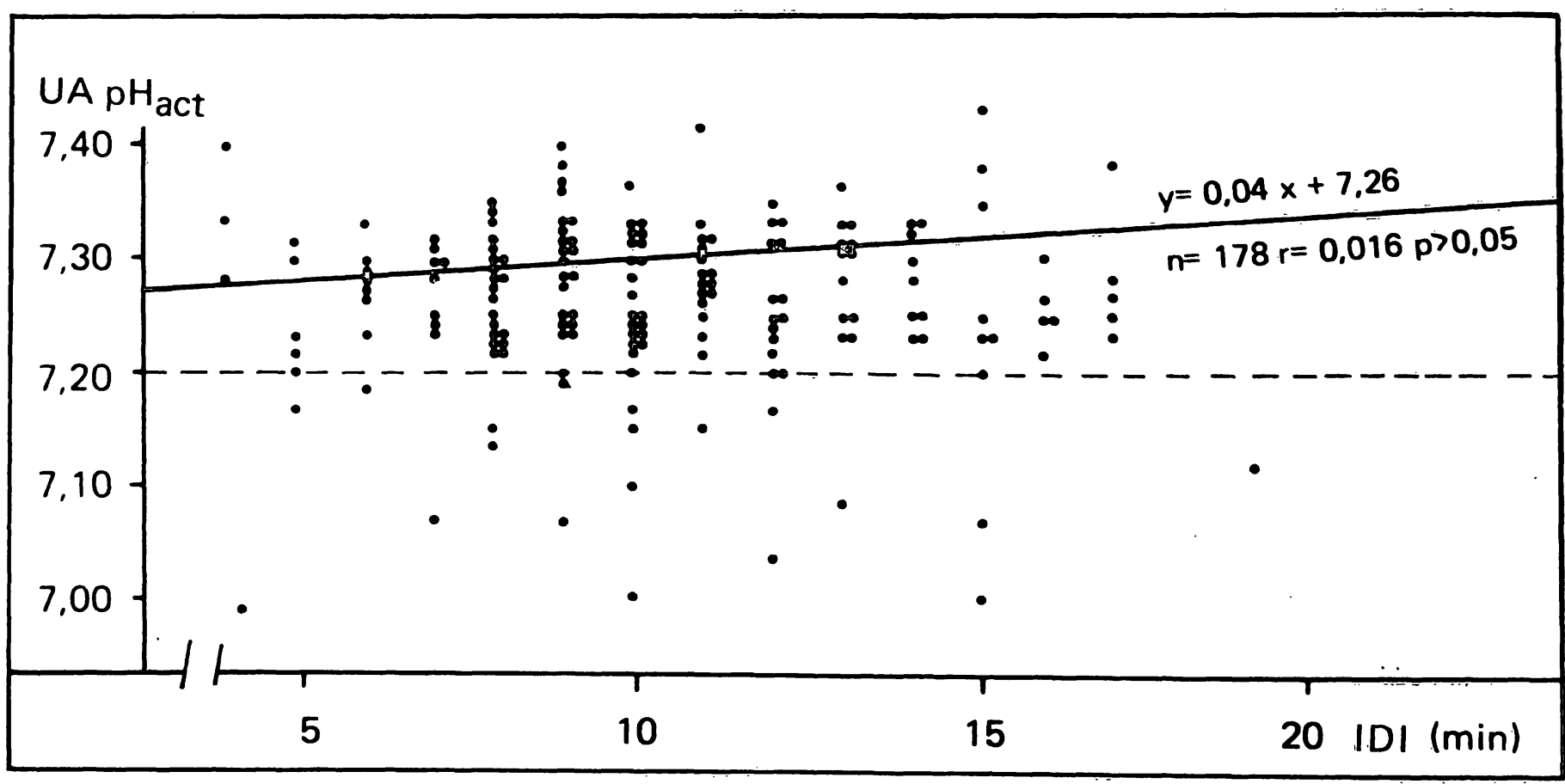

Fig. 2. Correlation between actual $\mathrm{pH}$ of the umbilical artery (UA) and the induction-delivery-interval (IDI) in cases with cesarean section for arrest of labor 
Tab. III. Behavior of oscillation amplitude and frequency according to the oscillation types after HAMMACHER in 178 cases with cesarean sections for arrest of labor in the pelvic inlet:

a) during the last 30 minutes prior to placing on the operating table

b) after placement on the operating table

\begin{tabular}{|c|c|c|c|c|c|}
\hline & \multicolumn{4}{|c|}{ Oscillation frequency $(\mathrm{N} / \mathrm{min})$} \\
\hline & & $<2$ & $\geq 2-<6$ & $\geq 6$ & $\Sigma$ \\
\hline \multirow{5}{*}{ 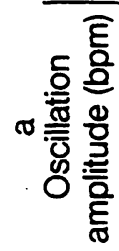 } & $\geq 25$ & 0 & 2 & 1 & 3 \\
\hline & $\geq 10-<25$ & 0 & 43 & 19 & 62 \\
\hline & $\geq 5-<10$ & 0 & 70 & 26 & 96 \\
\hline & $<5$ & 0 & 14 & 3 & 17 \\
\hline & $\bar{\Sigma}$ & 0 & 129 & 49 & 178 \\
\hline
\end{tabular}

\begin{tabular}{|c|c|c|c|c|c|}
\hline & \multicolumn{4}{|c|}{ Oscillation frequency $(\mathrm{N} / \mathrm{min})$} \\
\hline & & $<2$ & $\geq 2-<6$ & $\geq 6$ & $\Sigma$ \\
\hline & $\geq 25$ & 0 & 1 & 0 & 1 \\
\hline 들 을 & $\geq 10-<25$ & 0 & 30 & 10 & 40 \\
\hline م & $\geq 5-<10$ & 0 & 82 & 18 & 100 \\
\hline 员릉 & $<5$ & $\overline{4}$ & 31 & 2 & 37 \\
\hline & $\bar{\Sigma}$ & 4 & 144 & 30 & 178 \\
\hline
\end{tabular}

cardiotocogram. If one considers only the oscillation amplitude of the pre- and intraoperative cardiogram, 134 were unchanged. In 9 cases there was an increase in the amplitude and in 35 $(19.8 \%)$ a decrease. The changes in the oscillation frequency were more marked. While 96 cardiograms showed no change in oscillation frequency, in 60 cases $(33.7 \%)$ there was a decrease, and in $22(12.4 \%)$ there was an increase. In four cases after anesthesia the oscillation pattern $\mathrm{Oa}$ (oscillation amplitude $<5 \mathrm{bpm}$, oscillation frequency $<2 \mathrm{~N} / \mathrm{min}$ ) occurred; 3 newborns had a normal acid-base state and were vigorous. In only one case with additional severe bradycardia was there an acidotic and depressed newborn.

The baseline of 152 cardiograms showed no change. There was an increase in 16 instances $(>20 \mathrm{bpm})$, and in 10 instances there was a decrease $(>20 \mathrm{bpm})$ in the baseline.

The cardiograms were also evaluated for pathological heart rate patterns such as decelerations and bradycardia. As can be seen in Tab. IV, $108(60.7 \%)$ of the 178 cardiograms were without decelerations and without bradycardia. In $46(25.8 \%)$ decelerations occurred, and in 24 $(13.5 \%)$ bradycardia was noted. According to the degree of severity, 15 were classified as mild bradycardia (100-119 bpm) and 10 were severe $(<100 \mathrm{bpm})$. From the correlation between the condition of the newborn and pathological heart rate patterns, we found an increase of acidotic and depressed infants when decelerations and particularly when bradycardia occurred as can be seen from Tab. IV. Of 108 newborns with cardiograms without decelerations and without bradycardia, only 2 were acidotic, and 6 were clinically depressed.

Tab. IV. Heart rate patterns in cardiograms of 178 cases with cesarean section for arrest of labor in the pelvic inlet and the number of biochemically and clinically depressed newborns

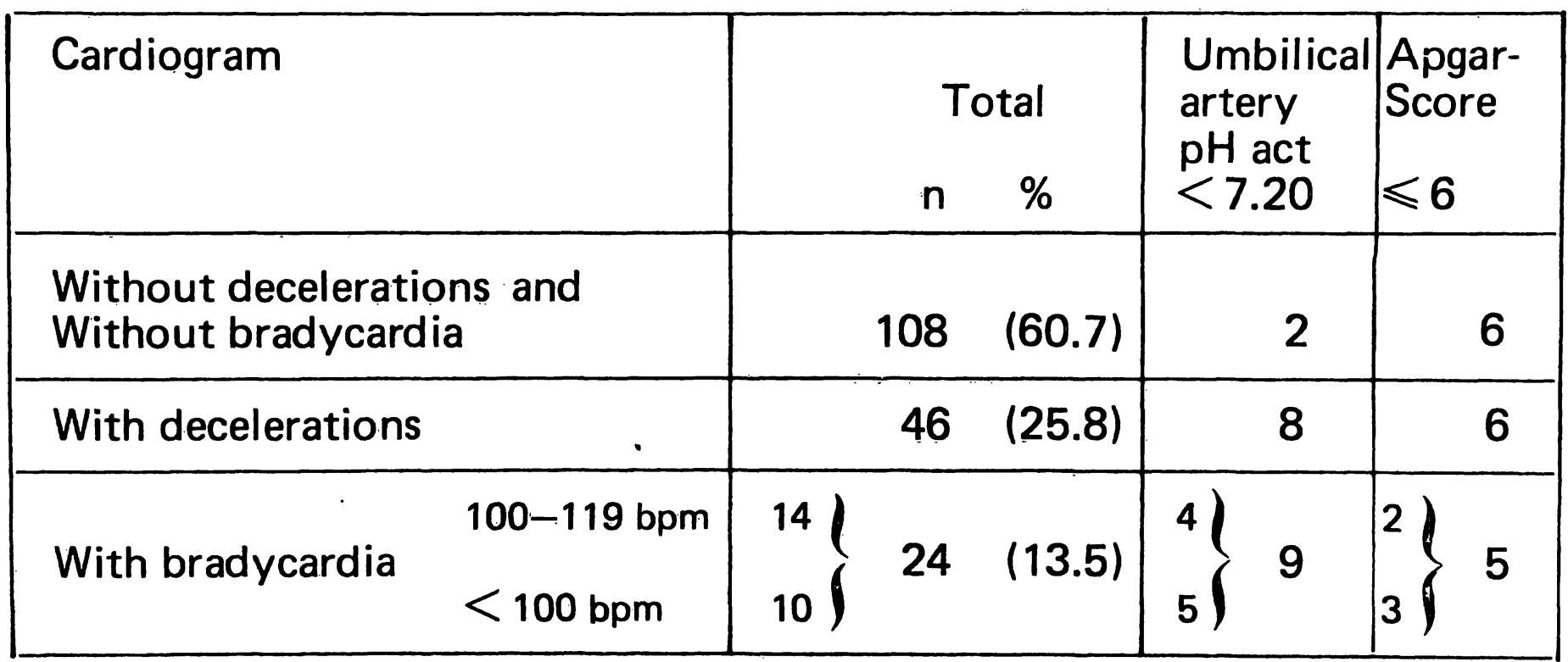


2.4 Cesarean sections in cases with preacidosis or acidosis

There were 99 infants with hypoxic risk during labor. Of these 66 were delivered by cesarean section because of acidosis, and 33 were delivered because of longer lasting preacidosis. As far as parity, maternal age and infant's weight were concerned, there were no great differences to be seen in the group of cesarean sections performed for arrest of labor (Tab. I). Corresponding to the indication, the median of the interval between anesthesia-induction and delivery was reduced to 7.9 minutes, and the median of the interval between incision and delivery to 5.9 minutes. The duration of the fetal heart rate recording on the operating table ranged from 4 to 20 minutes $(\tilde{\mathrm{x}}=8.1 \mathrm{~min})$.

\subsection{Condition of the newborn}

Of the newborns, 42 were optimally vigorous, 27 vigorous, 20 slightly depressed, 8 moderately depressed and 2 severely depressed (Tab. II). The evaluation of the umbilical artery $\mathrm{pH}$ values showed a normal acid-base state in only one case, slight to moderate acidity increase in 33 , slight to moderate acidosis in 41 , advanced acidosis in 18 and severe acidosis in 6 newborns. Twenty-four infants were acidotic and also clinically depressed (APGAR score $\leqslant 6$, actual $\mathrm{pH}<7.20$ ). Five of these infants had an APGAR score of $\leqslant 4$ combined with advanced; $q$ r severe acidosis (actual $\mathrm{pH}<7.10$ ). Fourty-one children had to be ventilated for a few minutes, and 22 had to be buffered through the umbilical vein.

\subsection{Cardiotocograms}

The evaluation of the last 30 minutes of the cardiotocogram before the patient was transferred into the operating room was normal in 4 cases, suspicious in 35, prepathological in 46 and pathological in 14 cases (HAMMACHER score).

A comparison of the oscillation types of the cardiotocogram with those of the cardiogram recorded during the operation demonstrated a clear shift in the direction of lower oscillation frequencies and amplitudes in this group. In only 32 cases $(32.3 \%)$ was there no change in the oscillation type. The oscillation frequency did not change in 70 cardiograms (70.7\%). In 11 cases there was an increase in frequency, and in 18 a decrease.

In comparison to the group first mentioned, there was a more frequent decrease in the oscillation amplitude in the group with cesarean sections for preacidosis or acidosis. The oscillation amplitude remained the same in 43 cardiograms, increased in 9 cases and decreased in $51(51.5 \%)$. Often there was a decrease in basal frequency too. In 15 cases

Tab. V. Heart rate patterns in cardiograms of 99 cases with cesarean section indicated by preacidosis or acidosis and the number of infants with a marked decrease of $\mathrm{pH}$ values $(>0.10 \mathrm{pH}$ units)

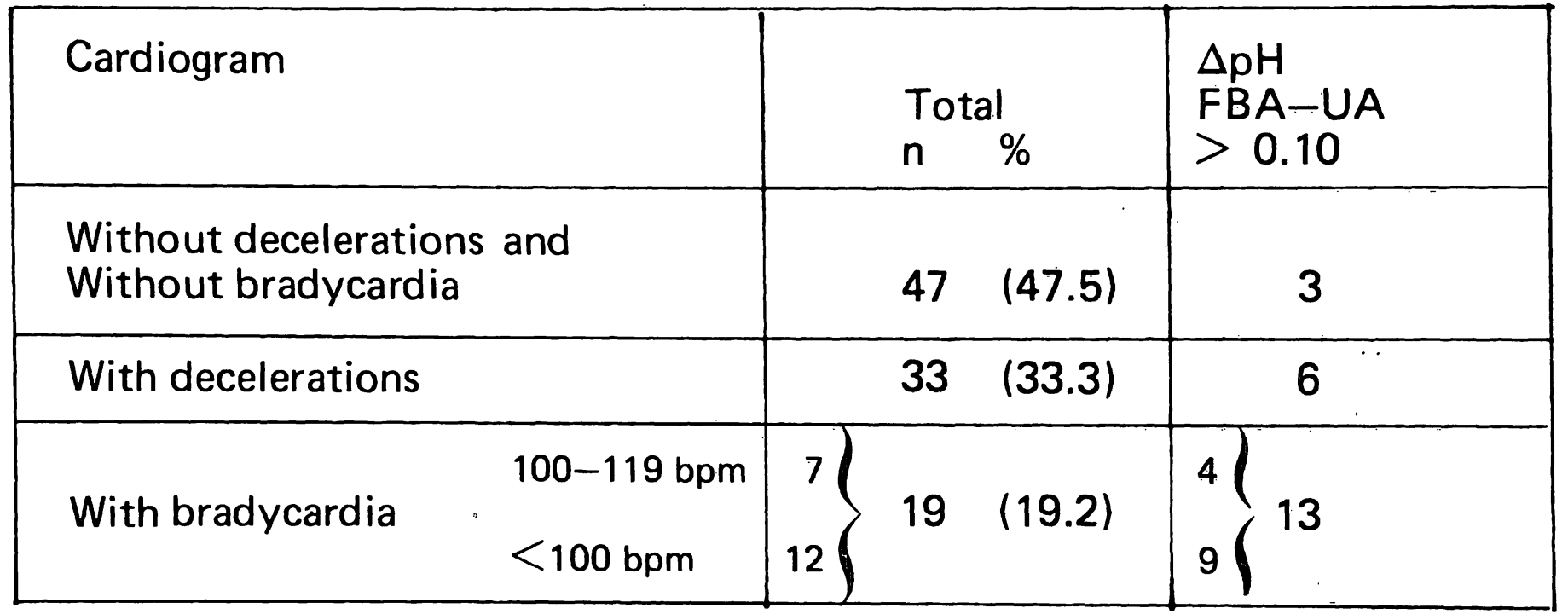


the basal frequency decreased ( $>20 \mathrm{bpm})$ and in 9 cases it increased $(>20 \mathrm{bpm})$, while no direct change could be established in 75 cardiograms.

Tab. $\mathrm{V}$ demonstrates the incidence of pathological heart rate pattern in the cardiograms for the 99 cesarean sections performed for preacidosis or acidosis. While 47 (47.5\%) cardiograms were without decelerations and bradycardia, there were decelerations in 33 cases (33.3\%). In 19 (19.2\%) cases bradycardia could be seen; in 7 slight and in 12 severe. These changes in the fetal heart rate pattern were correlated to the $\mathrm{pH}$-level drop between the actual $\mathrm{pH}$ of the fetal blood analysis and the umbilical artery blood. Among the 99 fetuses there was a drop of the $\mathrm{pH}$ level from $\mathrm{pH}_{\mathrm{FBA}-\mathrm{UA}}>0.10$ in 22 cases. In 47 cardiograms without pathological heart rate patterns, this difference occurred only 3 times. On the other hand cardiograms with decelerations in $1 / 5$ of the newborn and after bradycardia in $2 / 3$ of the newborn showed this drop in $\mathrm{pH}$ level.

\subsection{Three illustrative case reports}

The importance of continous recording of the fetal heart rate patterns on the operating table (cardiogram $=C G$ ) will be demonstrated in 3 cases .

Figs. $3 \mathrm{a}-\mathrm{c}$ show the monitoring of the fetal heartrate, and at $\uparrow a$ after placement of the patient on the operating table.

Case 1 (Fig. 3a): CG of a 22 year-old, para I with gestational age of 40 weeks with cesarean section for arrest of labor in the pelvic inlet. After placement and initiation of anesthesia, there was a reduction in the oscillation frequency, oscillation amplitude and also a decrease in the incidence of accelerations. Delivery of a vigorous boy with normal acid-base determinations, weighing $3970 \mathrm{~g}$, UA actual pH 7.31, pH (qu40) 7.32; APGAR score 8 at 1 and 10 at 5 minutes. ( $\mathrm{pH}$ (qu40) is the $\mathrm{pH}$ after equilibration with $40 \mathrm{~mm} \mathrm{Hg} \mathrm{pCO}_{2}$ and represents the metabolic acid-base state).

Case 2 (Fig. 3 b): 22 year-old, para I of 41 gestational weeks, fever during labor, cesarean section for arrest of labor in the pelvic inlet. The CTG shows a severe tachycardia $(\sim 190 \mathrm{bpm})$. A fetal blood analysis 27 minutes antepartum showed values in the normal range (actual $\mathrm{pH}: 7.40 ; \mathrm{pH}$ (qu40): 7.30). After induction of anesthesia, decelerations occurred in the CG and the basal frequency went down $(\sim 160 \mathrm{bpm})$. Delivery of a moderately acidotic and depressed female, weighing $3170 \mathrm{~g}$; UA actual $\mathrm{pH}: 7.11 ; \mathrm{pH}$ (qu40): 7.23; APGAR score 6 at 1 and 9 at 5 minutes.

Case 3 (Fig. 3 c): 32 year-old, para I, gestational age of 39 weeks with a cesarean section for arrest of labor in the pelvic inlet. Before and during placement on the operating table, no suspicious and/or pathological heart rate patterns were observed. After induction of anesthesia, bradycardia occurred. Delivery of a moderately acidotic vigorous female weighing $3450 \mathrm{~g}$, UA actual $\mathrm{pH}$ : 7.10, pH (qu40): 7.24; APGAR score 8 at 1 and 9 at 5 minutes.

\section{Discussion}

It has been known for a long time, from numerous studies of the condition of the newborn after cesarean section, that unexpected acidosis and depressed state occur in several of the cases. These impairments of the newborn can be caused or increased by the position of the patient and by the anesthesia. At the beginning of the 1970's, several authors drew attention to the importance of placing the mother in a left lateral position during the operation to avoid a supine hypotensive syndrome. When comparing primary cesarean sections in a horizontal position to left lateral maternal position $\left(15^{\circ}\right)$, ROEMER [11] was able to demonstrate significantly higher $\mathrm{pO}_{2}$ values in the arterial cord blood as well as an improved base excess. Because of the left lateral position of the mother, the compression of the vena cava and the abdominal aorta by the pregnant uterus can be prevented or reduced. In this way, danger to mother and infant triggered by the supine position with lower heart minute volume and reduced uteroplacental perfusion can be lessened [7]. RALSTON [9] reported that an acute aortocaval syndrome can be expected in 1 to $6 \%$ of the cases even with adequate positioning. For the rarely recognizable dangers of this syndrome which occur more frequently and which do not lead to a drop in the maternal blood pressure, CRAWFORD [2] created the expression "concealed caval-occlusions-sydrome". 


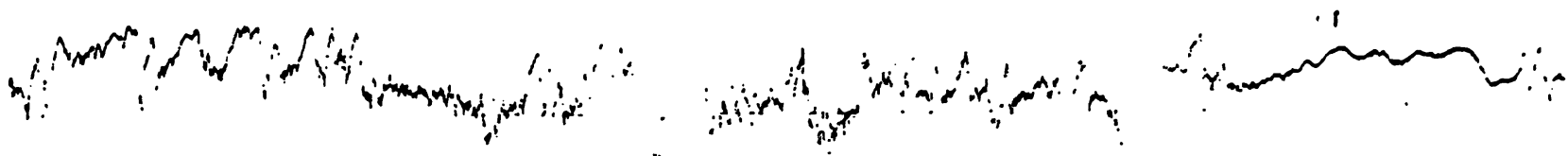

$\underset{1 \mathrm{~cm} / \mathrm{min}}{\sim} \quad$ Anesthetic incision $\begin{gathered}\text { Delivery } \\ \text { UApHact:731 } \\ \text { pHqu } 40.732\end{gathered}$

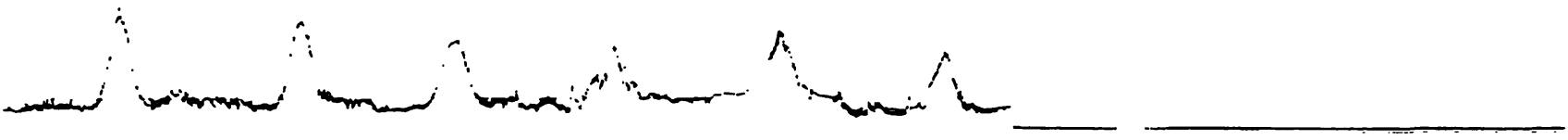

Geb.Nr:1205/78
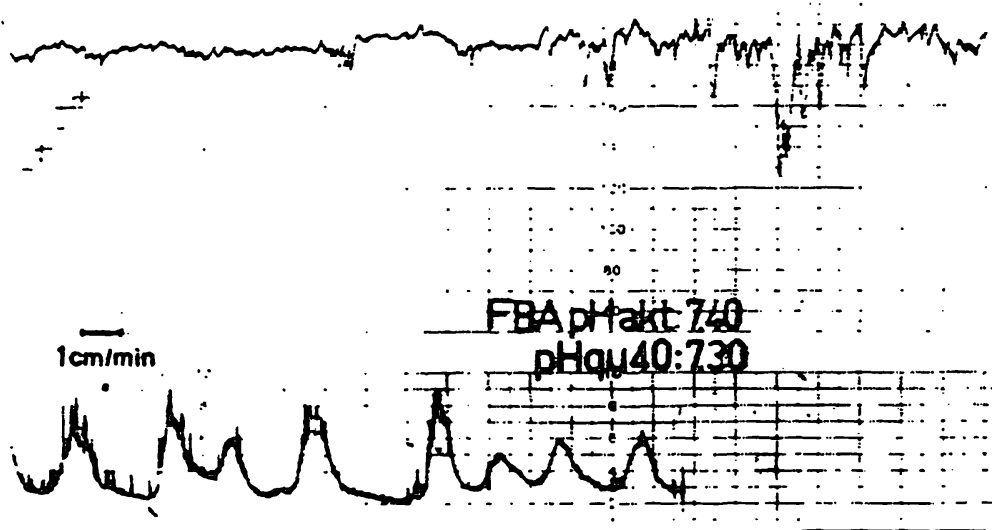

Geb. Nr: $547 / 80$

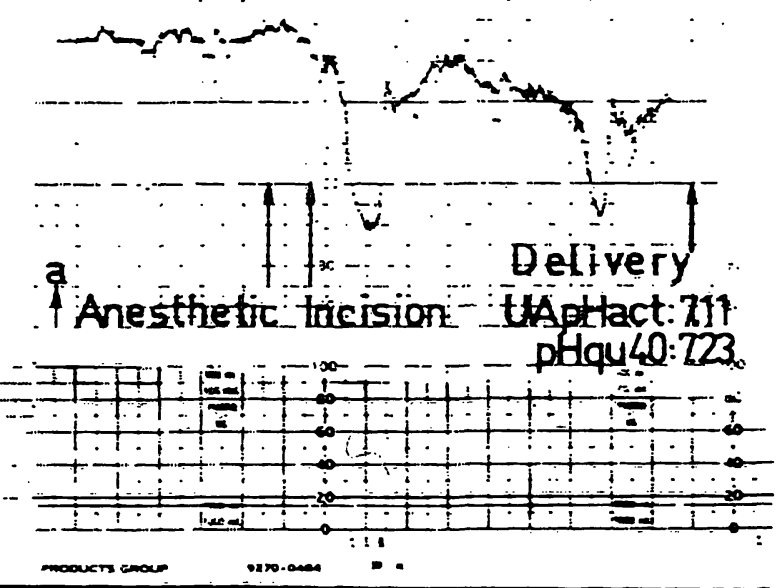

-

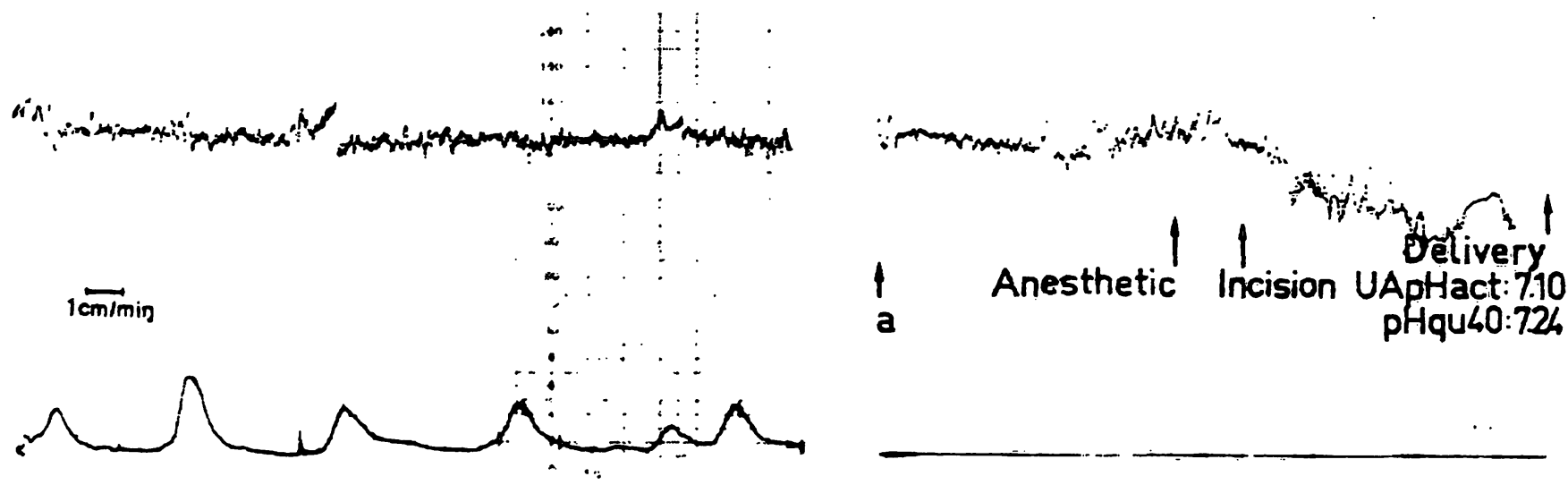

\section{Geb.Nr:1458/76}

Fig. $3 \mathrm{a}-\mathrm{c}$. Continuous monitoring of fetal heart rate on the operating table before and at $\uparrow a$ after placement of the patients. For explanation see text. 
The negative influence caused by barbiturates on the fetal circulation can be responsible for the worsening of the child's condition during the operation [12]. Due to the anesthesia, the vasoconstriction is partially removed which would otherwise begin when chronic or respiratory insufficiency occurs in the fetus as a protective mechanism to organs exposed to hypoxic risk, and this leads to general increase in hypoxia and acidosis.

It is not possible to compare our results with other studies due to the different composition of the material. In our study no primary (this means elective) cesarean sections were included and we did not choose "clinically acceptable ideal cases [2]". This is clear from the different frequency of pathological fetal heart rate patterns on the operating table in the two groups we examined.

In the cesarean sections performed for arrest of labor, decelerations were observed in $25.8 \%$ of the cases and bradycardia in $13.5 \%$; although in the group with fetuses already at risk due to signs of hypoxia, decelerations occurred in $33.3 \%$ and bradycardia in $19.2 \%$. On the other hand, HARMS and ROEMER [5] in antepartum cardiotocograms from 1606 patients, who had still not started labor and who had no impairment due to anesthesia, could only find a fetal heart-rate pattern in $0.7 \%$ of the cases which could have been caused by a caval-occlusions syndrome. In addition to various fetal stresses occurring during the course of labor, factors caused by anesthesia also play an important part. After the initiation of anesthesia there was a clear shift of the oscillation types to lower oscillation frequency and amplitude. Similar changes in heart rate on the operating table were reported by ROEMER and coworkers [10] in a small series. This "fixation of the heart rate" is one of the well known reactions of the fetus to drugs such as atropine, sedatives and opiates.

In the group of cesarean sections performed for arrest of labor, $10.7 \%$ of the newborns were acidotic and $9.5 \%$ clinically depressed. The number of acidotic or depressed infants increased with the pathology of the cardiogram. Initially the fetuses were not at risk according to the cardiotocograms and fetal blood analyses.

The cardiogram permits the retrospective explanation for acidosis and depression which occurred during the last minutes before delivery.

With continuous recording of the fetal heart rate from the operating table, the obstetrician is given the opportunity of recognizing fetal danger after deciding on a cesarean section and before the delivery of the infant; furthermore, in cases where the cesarean was originally not considered urgent, the fetus can be delivered immediately in a case of a pathological cardiogram. This plays a practical role in cesarean sections being performed by assistant physicians in training under the supervision of a specialist. Here it is recommended, should suspect or pathological heart rate patterns occur, to change so that the cesarean section can be performed more quickly by an experienced physician. If this method of monitoring is not practized, as for example in elective cesarean sections, then a shorter induction-delivery-interval must be aimed at.

\section{Summary}

Despite improvements in anesthesia procedures, there is sometimes an unexpected worsening in the condition of the newborn in cases of cesarean section.

In order to detect a possible hypoxic risk to the fetus occurring in the final intrauterine period, we have been monitoring the fetal heart rate on the operating table as a routine practice for many years in cases with cesarean section.

At the Department of Obstetrics in Berlin-Neukölln Hospital during a period of five years, the fetal heart rate was recorded by a cardiotocograph (HP $8020 \mathrm{~A}$ ) from the time of placement on the operating table until the beginning of the uterine incision in 277 cesarean section performed with general anesthesia. Of these, 178 were for arrest of labor in the pelvic inlet and 99 for longer lasting preacidosis or early acidosis.

In the group of 178 non-emergency cesarean sections for arrest of labor in the pelvic inlet, there was no sign of hypoxic risk to the fetus when the indication had been decided. Of these 178 newborns, 161 were born in a clinically vigorous state and 159 were in a normal acidbase state; 17 (9.5\%) were clinically depressed (APGAR $\leqslant 6)$ and $19(10.7 \%)$ were acidotic (umbilical artery actual $\mathrm{pH}<7.20$ ). The examination of the newborns' condition dependent on the anesthesia-delivery-interval showed no significant correlation $(p>0.05)$ either as regards to the APGAR score or the actual $\mathrm{pH}$ level in the umbilical artery. 
Following administration of anesthesia a change of oscillation types to a lower frequency and amplitude occurred in the cardiogram of the fetus which was probably due to medication. Thus, the oscillation pattern after the anesthesia has been given cannot be used as a parameter for the diagnostic state of the newborn. Pathological heart rate frequency patterns occurred in the form of decelerations in $46(25.8 \%)$ and in the form of bradycardia in $24(13.5 \%)$ of the 178 cardiograms. Whereas an increase in the number of acidotic and depressed infants could be seen after occurrence of decelerations and in particular after bradycardia, only 2 newborns were acidotic and 6 were clinically depressed from 108 cases with cardiograms without pathological heart rate patterns.

In the group of 99 cesarean sections indicated by longer lasting preacidosis or early acidosis, there were 33 cardiograms with decelerations and 19 with bradycardia. The occurrence of pathological fetal heart rate patterns was clearly associated with the worsening of the infant's condition.

Keywords: APGAR score, cardiotocography, cesarean section, supine hypotension syndrome.
The cardiogram enables us to recognize a possible risk of a worsening in the infants' condition after anesthesia has been started, and it permits ai shortening of the anesthesiadelivery-interval time in these cases by shortening the duration of the operation. For example, from the practical side, in cesarean sections being performed by assistants in training under the supervision of a specialist, should suspicious or pathological heart-rate patterns occur, then the operation should be taken over by the experienced physician and continued without further loss of time. Furthermore, it is possible to obtain a retrospective interpretation of depressed conditions and acidosis occurring unexpectedly in the newborn, where the fetuses were not previously at hypoxic risk.

For the above mentioned reasons, it is recommended to perform a continuous recording of the fetal heart rate on the operating table in cesarean sections as a routine measure.

If cardiographic supervision on the operating table is not possible, as is the case for example in elective cesarean sections, then in general a short anesthesia-deliveryinterval should be aimed at.

\section{Zusammenfassung}

Registrierung der kindlichen Herzfrequenz auf dem Operationstisch bei abdominalen Schnittentbindungen Trotz verbesserter Anästhesieverfahren kommt es in einem Teil der Fälle bei abdominalen Schnittentbindungen $\mathrm{zu}$ unerwarteten Beeinträchtigungen der Neugeborenen.

Um eine möglicherweise in der letzten intrauterinen Phase auftretende hypoxische Gefährdung des Feten zu erfassen, setzen wir deshalb seit Jahren routinemäßig bei sekundär indizierten Schnittentbindungen die Registrierung der fetalen Herzfrequenz auf dem Operationstisch fort.

In einem Zeitraum von 5 Jahren wurde an der Abteilung für Geburtsmedizin des Krankenhauses Berlin-Neukölln bei 277 sekundär indizierten abdominalen Schnittentbindungen in Allgemeinanästhesie, davon 178 wegen Geburtsstillstandes in Beckeneingang und 99 wegen anhaltender Präazidose oder wegen beginnender Azidose, die fetale Herzfrequenz auf dem Operationstisch bis zu Beginn der Uterotomie mit einem Kardiotokographen (HP 8020 A) registriert.

In der Gruppe der nicht dringlich durchgeführten 178 abdominalen Schnittentbindungen wegen Geburtsstillstandes im Beckeneingang bestand bei allen Kindern zum Zeitpunkt der Indikationsstellung kein Anhalt für eine hypoxische Gefährdung. Von diesen 178 Neugeborenen waren 161 in klinisch lebensfrischen und 159 in normazidem Zustand geboren worden, während $17(9,5 \%)$ deprimiert (APGAR $\leqslant 6$ ) und $19(10,7 \%)$ azidotisch (Umbilicalarterien pHact $<7,20$ ) waren. Die Untersuchung des Neugeborenen-Zustandes in Abhängigkeit von der Narkoseeinleitungs-Entwicklungszeit ergab sowohl für den APGAR-Score als auch für den aktuellen
pH-Wert in der Nabelarterie keine signifikante Korrelation (p > 0,05).

Nach Narkoseeinleitung trat im Kardiogramm der Feten eine wahrscheinlich medikamentös bedingte Verschiebung der Oszillationstypen zu niedrigerer Oszillationsfrequenz und -amplitude auf. Die Oszillationsbefundung stellt somit nach Narkoseeinleitung keinen brauchbaren Parameter für die Zustandsdiagnostik des Neugeborenen dar.

Pathologische Herzfrequenzmuster traten in Form von Dezelerationen in $46(25,8 \%)$ und Bradykardien in $24(13,5 \%)$ der 178 Kardiogramme auf. Konnte eine Zunahme der azidotischen und deprimierten Kinder beim Auftreten von Dezelerationen und insbesondere bei Bradykardien verzeichnet werden, so waren von den 108 Fällen mit Kardiogrammen ohne pathologische Herzfrequenzmuster nur 2 Neugeborene azidotisch und 6 klinisch deprimiert.

Im Kollektiv der 99 Schnittentbindungen wegen anhaltender Präazidose oder beginnender Azidose traten in 33 $(33,3 \%)$ Kardiogrammen Dezelerationen und in 19 $(19,2 \%)$ Bradykardien auf. Das Auftreten von pathologischen Herzfrequenzmustern stand in engem Zusammenhang mit der Verschlechterung des kindlichen Zustandes.

Das Kardiogramm läßt eine mögliche Gefahr der Verschlechterung des kindlichen Zustandes nach Narkoseeinleitung erkennen und erlaubt in diesen Fällen durch Steigerung der Operationsgeschwindigkeit eine Verkürzung der Narkoseeinleitungs-Entwicklungszeit. Eine praktische Rolle spielt dies z.B. bei abdominalen Schnittentbindungen, die von den in Ausbildung befindlichen Assistenten unter Aufsicht eines Facharztes mit der entsprechenden Sorgfalt des noch Unerfahrenen durchgeführt werden. Hier empfiehlt es sich, mit Auftreten suspekter oder 
pathologischer Herzfrequenzmuster umzudisponieren, so daß die Sektio von diesem Zeitpunkt an von einem Erfahrenen zügig fortgesetzt wird. Ferner ist eine retrospektive Deutung unerwartet aufgetretener Depressionszustände und Azidosen der Neugeborenen bei ursprünglich nicht gefährdeten Feten möglich.

Aus den genannten Gründen empfiehlt es sich, die routinemäßige kontinuierliche Registrierung der fetalen Herz- frequenz auf dem Operationstisch bei sekundär indizierten abdominalen Schnittentbindungen durchzuführen.

Ist eine kardiographische Überwachung auf dem Operationstisch nicht realisierbar, wie dies $z$. B auch für primär indizierte Schnittentbindungen zutrifft, so sollte generell eine kurze Narkoseeinleitungs-Entwicklungszeit angestrebt werden.

Schliisselwörter: APGAR-Schema, Kardiotokographie, Vena-Cava-Kompressions-Syndrom.

\section{Résumé}

Enregistrement du rythme cardiaque foetal sur la table d'opération immédiatemment avant la naissance par césarienne

En dépit de l'amélioration des techniques anesthésiques, il $y$ a parfois une aggravation inattendue de l'état du nouveau-né, en cas de césarienne.

Les auteurs ont enregistré en routine le rythme cardiaque foetal sur la table d'opération pendant de nombreuses années dans les cas de césarienne afin de détecter un risque possible d'hypoxie.

$\mathrm{Au}$ département d'obstétrique de l'hôpital de Berlin-Neukölln pendant une période des ans, le rythme cardiaque foetal a été enregistré à l'aide d'un cardiotocographe (HP 8020 A) de la mise sur la table d'opération jusqu'au commencement de l'hystérotomie, au cours de 277 césariennes sous anesthésie générale. Parmi celles-ci, 178 ont été effectuées pour arrêt du travail au détroit supérieur et 99 pour une préacidose trop durable ou une acidose débutante.

Dans le groupe des 178 césariennes non urgentes effectuées pour arrêt du travail au détroit supérieur, il n'y avait pas de signes de risque d'hypoxie quand l'indication a été posée. Parmi ces 178 nouveaux-nés, 161 sont nés avec un état clinique robuste, et 159 avec un équilibre acidobasique normal; $17(9,5 \%)$ étaient déprimés cliniquement $(A P G A R \leqslant 6)$ et $19(10,7 \%)$ en état d'acidose ( $\mathrm{pH}$ artériel ombilical $<7,20$ ). L'examen chez les nouveauxnés des éléments dépendants de l'intervalle anesthésieextraction n'a pas montré de corrélation significative ( $p>0,05)$ tant pour le score d'APGAR que pour le résultat du $\mathrm{pH}$ artériel ombilical.

Une modification des types d'oscillations avec un abaissement de la fréquence et de l'amplitude est apparue sur le cardiogramme foetal après l'induction anesthésique, vraissemblablement secondaire aux médications. De telle sorte que le niveau des oscillations après le début de l'anesthésie ne peut être utilisé comme paramètre diagnostic de l'état du nouveau-né. Parmi les 178 enregistrements, $46(25,8 \%)$ ont montré des aspects pathologiques de la fréquence cardiaque foetale sous forme de décélérations et $24(13,5 \%)$ sous forme de bradycardie. Alors que l'on peut observer une augmentation du nombre d'enfants en acidose et déprimés après la survenue de décélérations et tout particulièrement après la survenue de bradycardie, 2 nouveaux-nés seulement étaient en état d'acidose et 6 étaient cliniquemùent déprimés parmi les 108 cas avec un cardiogramme nc présentant pas d'aspect pathologique du rythme cardiaque.

Dans le groupe des 99 césariennes effectuées pour une préacidose trop durable ou une acidose débutante, il y a 33 cardiogrammes avec des décélérations et 19 avec une bradycardie. La survenue d'aspects pathologiques du rythme cardiaque est clairement en rapport avec une aggravation de l'état des enfants.

Le cardiogramme nous permet de reconnaitre la possibilité d'un risque d'aggravation de l'état des enfants après l'induction anesthésique et permet de raccourcir le temps de l'intervalle anesthésie extraction dans ces cas en diminuant la durée de l'intervention. Par exemple, d'un point de vue pratique, pour les césariennes réalisées par les internes en formation sous la supervision d'un spécialiste, en cas de suspicion ou d'aspect pathologique du rythme cardiaque, alors l'intervention doit être prise en charge par le praticien exérimenté et poursuivie sans la moindre perte de temps. En outre, il est possible d'avoir une interprétation rétrospective des états de dépressions ou d'acidose des nouveaux-nés, survenant de manière inattendue, alors que les foetus n'étaient pas précédemment à risque d'hypoxie.

Pour les raisons mentionnées ci-dessus, il est recommandé d'enregistrer en continu la fréquence du rythme cardiaque foetal sur la table d'opération au cours des césariennes, et cela en routine.

Si le contrôle cardiographique sur la table d'opération n'est pas possible, comme c'est le cas par exemple pour les césariennes itératives, alors en général il faut viser à obtenir un intervalle induction-extraction court. 


\section{Bibliography}

[1] ANSARI, J., G. WALlace, C. A. B. Clementson: Tilt caesarean section. J. Obstet. Gynaec. Brit. Cwlth. 77 (1970) 713

[2] CRAWford, J. S., M. BURTON, P. DAVIES: Time and lateral tilt at caesarean section. Brit. J. Anaesth. 44 (1972) 477

[3] Finster, M., H. O. MORIShima, F. MOYA, J. M. PEREL, L. S. JAMES, P. G. DAYTON: Plasma thiopental concentrations in the newborn following delivery under thiopental-nitros oxide anesthesia. Amer. J. Obstet. Gynec. 95 (1966) 621

[4] HAMMACHER, K., R. BRANDEL, R. GAUDENZ, P. DE GRANDI, R. RICHTER: Kardiotokographischer Nachweis einer fetalen Gefährdung mit einem CTG-Score. Gynäk. Rdsch. 14 (1974) 61

[5] HARMS, K., V. M. ROEMER: Häufigkeit, Morphologie und Aetiologie von antepartualen, fetalen Herzfrequenzmustern bei Vena-Cava-Kompressionssyndrom der Mutter. In: DUDENHAUSEN, J.W., E. SALING, E. SCHMIDT (eds.): Perinatale Medizin, Bd. VI. Thieme, Stuttgart 1975

[6] LANGREHR, D., W. STOLP, J. KLUGE, A. HAAS: Ketamine - Anästhesie für geburtshilfliche gynäkologische Eingriffe. Z. Prakt. Anästh. 5 (1970) 145

[7] LEMTIS, H. G., R. SEGER: Das Rückenlage-Schocksyndrom. Walter de Gruyter, Berlin 1973

[8] LUMLEY, J., A. WALKER, J. MARUM, C. WOOD: Time: An important variable at caesarean section. J. Obstet. Gynaec. Brit. Cwlth. 77 (1970) 10

[9] RALSTON, D. H., S. M. SHNIDER: The fetal and neonatal effects of regional anesthesia in obstetrics. Anesthesiology 48 (1978) 34
[10] ROEMER, V. M., F. LEUENBERGER, G. FLURI, E. WILLI, E. RUPPIN, H. NEESER, W. DIEKMANN, E. STOLZ: Azido-basische, elektrokardio- und kardiotokographische Befunde bei Schnittentbindungen. In: SALING, E., J. W. DUDENHAUSEN (eds.): Perinatale Medizin, Bd. III. Thieme, Stuttgart 1972

[11] ROEMER, V. M., L. CASAGRANDE, F. LEUEN BERGER, D. RADACOVIC: Zustand des Neugeborenen nach Schnittentbindung bei Schräglagerung $\left(15^{\circ}\right)$ der Mutter während der Operation. Geburtsh. u. Frauenheilk. 33 (1973) 938

[12] SALING, E. Z.: $\mathrm{O}_{2}$-conserving adaption of foetal circulation. Modern trends in paediatrics 3 (1970) 51

[13] SCOTT, D. B., M. M. LEES, J. T. DAVIES, K. B. SLAWDON, M. G. KERR: Observations on cardiorespiratory function during caesarean section. Brit. J. Anaesth. 41 (1969) 489

[14] STENGER, V. G., J. N. BLECHNER, H. PRYTOWSKY: A study of prolongation of obstetric anesthesia. Amer. J. Obstet. Gynec. 103 (1969) 901

[15] TERAMO, K.: Foetal acid-base values during caesarean section. Lancet II (1968) 1146

[16] WALDRON, K. W., C. WOOD: Cesarean section in the lateral position. Obstet. and Gynec. 37 (1971) 707

Received March 25, 1982. Accepted November 29, 1982.

Dr. M. Pluta

Arbeitsgruppe Perinatale Medizin Mariendorfer Weg 28

D-1000 Berlin 44

FRG 